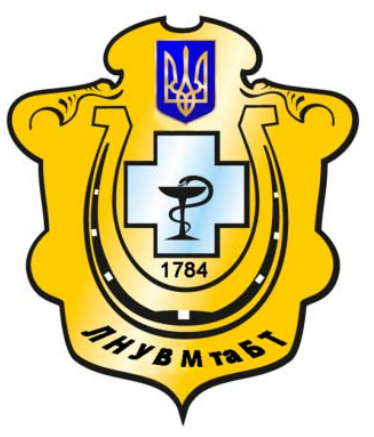

Науковий вісник Львівського національного університету ветеринарної медицини та біотехнологій імені С.3. Гжицького

Scientific Messenger of Lviv National University of Veterinary Medicine and Biotechnologies named after S.Z. Gzhytskyj

doi:10.15421/nvlvet7001

ISSN 2413-5550 print

ISSN 2518-1327 online

$\underline{\text { http://nvlvet.com.ua/ }}$

УДК 636.085.12.25.22/28

\title{
Мінеральні добавки, як один із чинників впливу на процеси біосинтезу мі- кробіального білку у жуйних тварин
}

\author{
С.Л. Антіпін, I.О. Жукова, К.Д. Югай, О.М. Бобрицька, Л.А. Водоп’янова, Н.І. Лонгус \\ irinaalekseevnazhukova@gmail.com \\ Харківська державна зооветеринарна академія, \\ вул. Академічна, 10, смт. Мала Данилівка, Дергачівський район, Харківська обл., 62341, Україна
}

Представлені результати досліджень по вивченню впливу різного рівня мінеральних речовин, щьо додавалися до фонового рачіону бичків на надходження хімусу, сухої речовини, органічних речовин, сирого протеїну із передшлунків до дванадиятипалої кишки. Перед початком дослідів тварини були прооперовані з накладенням анастомозів на початку дванадиятипалої кишки, на відстані 8-12 см від сичугу, до впадіння в кишечник підилункової залози.

У фізіологічних дослідах вивчали перетравність органічних речовин під впливом додавання до фонового рачіону хлориду натрію, хлориду кобальту, сульфатів міді і иинку, як окремо, так і в комплексі. Відмічено, щзо зі збільшенням об'сму хімусу, що надходив до дванадиятипалої кишки перетравність органічних речовин в передилунках знижувалася, що підтверджується зворотною корелячійною залежністю.

Встановлено, щчо додавання до фонового раціону мінеральних солей призвело до збільшення надходження в тонкий кишечник органічних речовин, як в иілому, так і окремо сирого протеїну.

3'ясовано, щцо додавання до фонового рачіону мінеральних речовин призвело до активізачії прочесів біосинтезу мікробіального білку в передилунках бичків з використанням ендогенних джерел азоту.

Ключові слова: мінеральні речовини, мікробіальний білок, сирий протеїн, ендогенний азот, органічні речовини, рубець, тонкий кишечник, передчлунки, дванадиятипала кишка, хімус, фоновий рачіон, перетравність.

\section{Минеральные добавки, как один из факторов влияния на процессы биоси- нтеза микробиального белка у жвачных животных}

\author{
С.Л. Антипин, И.А. Жукова, К.Д. Югай, О.Н. Бобрицкая, Л.А. Водопьянова, Н.И. Лонгус \\ irinaalekseevnazhukova@gmail.com
}

Харьковская государственная зооветеринарная академия,

ул. Академическая, 10, пгт. Малая Даниловка, Дергачевский район, Харьковская обл., 62341, Украина

\begin{abstract}
Представлены результаты исследований по изучению влияния различного уровня минеральных веществ, добавлявщихся к фоновому рачиону бычков на поступление химуса, сухого вещества, органических веществ, сирого протеина из преджелудков в двенадиатиперстную кишку. Перед началом опытов животные были прооперированы с наложением анастомозов в начале двенадцатиперстной кишки, на расстоянии 8-12 см от сычуга, до впадения в кишечник поджелудочной железы.

В физиологических опытах изучали переваримость органических веществ под влиянием добавления к фоновому рациону хлорида натрия, хлорида кобальта, сульфатов меди и ичинка, как по отдельности, так и в комплексе. Отмечено, что с увеличением объема химуса, поступающего в двенадиатиперстную кишку, переваримость органических веществ в преджелудках снижалась, что подтверждается обратной корреляционной зависимостью.

Установлено, что добавление к фоновому рациону минеральных солей привело к увеличению поступления в тонкий кишечник органических веществ в целом, так и в отдельности сырого протеина.
\end{abstract}

\section{Citation:}

Antipin, S.L., Zhukova, I.A., Yugay, K.D., Bobrytskaya, O.N., Vodopyanova, L.A., Longus, N.I. (2016). Mineral additives as a factor of influence on processes of biosynthesis of microbiological protein of ruminant animals. Scientific Messenger LNUVMBT named after S.Z. Gzhytskyj, 18, 3(70), 3-7. 
Выяснено, что добавление к фоновому рациону минеральных веществ привело к активизации процессов биосинтеза микробиального белка в преджелудках бычков с использованием эндогенных источников азота.

Ключевые слова: минеральные вещуества, микробиальный белок, сырой протеин, эндогенный азот, органические вещества, рубец, преджелудки, тонкий кишечник, двенадцатиперстная кишка, химус, фоновый рацион, переваримость.

\title{
Mineral additives as a factor of influence on processes of biosynthesis of micro- biological protein of ruminant animals
}

\author{
S.L. Antipin, I.A. Zhukova, K.D. Yugay, O.N. Bobrytskaya, L.A. Vodopyanova, N.I. Longus \\ irinaalekseevnazhukova@gmail.com \\ Kharkov state zooveterinary academy, \\ Academic Str., 10, village Small Danilovka, Dergachi district, Kharkiv region, 62341, Ukraine
}

Results of researches on studying the influence of various levels of the mineral substances that were added to a diet of bullcalves on getting of chyme, dry substances, organic substances, raw protein from prestomachs to duodenum are presented. Before the experiment animals have been operated with imposing of anastomosis at the beginning of a duodenum, at the distance of 8-12 cm from abomasus before the falling of pancreas into intestines.

Nowadays rationing of mineral food of animals is carried out by two ways: by amount of mineral substances on one animal a day or by its quantity on one kilogram of the consumed solid forage.

In our experiments mineral substances were brought in $1 \mathrm{~kg}$ of the consumed solid forage as it allows to create a certain concentration of the studied connections in the substance of the rumen.

During the preparatory period animals were on the diet for two weeks, then within 7 days they were used in experiments to define digestibility of nutrients in gastrointestinal tract. After completion of experiment on digestibility there was a physiological experiment to determine daily volume and structure of the chyme proceeding through inosculation of chyme. In forage and on average daily tests of a duodenal chyme and faeces the content of solids and also organic substances (with the difference between amount of solid and mineral substances) of a raw protein, raw fat, raw cellulose and the anazotic extractive substances by common techniques of the zoochemical analysis were determined.

In physiological experiments digestibility of organic substances under the influence of addition of chloride of sodium, chloride of cobalt, sulfates of copper and zinc to a diet separately and in the complex were studied. It was indicated that with the increase of chyme, coming to a duodenum, digestibility of organic substances in prestomachs decreased that was also confirmed by the inverse correlation dependence. It was proved that addition of mineral salts to a diet has led to increase of getting of organic substances in a small intestine as a whole and also of a raw protein.

It was found that addition of mineral substances to a diet has led to activation of processes of biosynthesis of microbiological protein in prestomachs of bull-calves with the use of endogenous sources of nitrogen.

Key words: mineral substances, microbiological protein, raw protein, endogenous nitrogen, organic substances, hem, prestomachs, small intestine, duodenum, chyme, diet, digestibility.

\section{Вступ}

У передшлунках жуйних тварин відбувається руйнування значної частини протеїну корму і синтез мікробіального сирого протеїну (білку і нуклеїнових кислот), що входить до складу мікробіальної клітини. При цьому кількість протеїну, що надходить 3 передшлунків в сичуг і кишечник, залежить від забезпеченості організму енергією. При вмісті сирого протеїну 10,5 - 13,5 г на 1 МДж доступної для обміну енергії в тонкий кишечник надходить близько 100\% сирого протеїну по відношенню до прийнятого (Cjupko, 1987).

Завдяки двосторонній проникності стінки рубця в порожнину передшлунків надходять ендогенні джерела азоту у формі сечовини, сироваткових білків, а також епітеліальних клітин слизової оболонки рубця, які злущуються. Ендогенні азотисті сполуки руйнуються в рубці до амінокислот і аміаку і використовуються у біосинтезі мікробіального сирого протеїну, що надходить в тонкий кишечник. На надходження сирого протеїну в тонкий кишечник чинять вплив його концентрація в раціоні, розчинність, доступність для мікрофлори і час перебування часток корму в передшлунках. Крім того у жуйних тварин для ство- рення сприятливих умов мікробіальної життєдіяльності в передшлунках потрібні мінеральні речовини. Макро і мікроелементи входячи до складу біокаталізаторів, виконуючи ферментативну, гормональну i вітамінну функції в організмі беруть участь в регуляції метаболізму. Проте про вплив мінеральних речовин на процеси біосинтезу мікробіального білку в передшлунках жуйних інформації не вистачає (Cjupko et al., 1995).

\section{Матеріал і методи досліджень}

Досліди були проведені в умовах фізіологічного двору лабораторії фізіології живлення інституту тваринництва УААН на бичках симентальської породи. Маса тварин на момент початку досліджень складала в середньому 294 кг, а на момент завершення досліджень - 340,5 кг. В підготовчий період тваринам накладали анастомози на початку дванадцятипалої кишки, на відстані 8 - 12 см від сичуга, до впадіння в кишечник протоки підшлункової залози. Тварини утримувалися на основному раціоні, який вміщував кукурудзяний силос - 9 кг, ячмінну солому -2 кг, ячмінну дерть - 1,6 кг. Дані, отримані на тлі основного раціону, служили контролем. У 2, 3 і 4 дослідах до 
основного раціону додавали відповідно - 30 г $\mathrm{NaCl}$; $30 г \mathrm{NaCl}+0,56$ мг Кобальту і $30 г \mathrm{NaCl}+0,56$ мг Кобальту, 224 мг Цинку і 56 мг Кипруму (табл.1). Мінеральні речовини вводилися в раціон з розрахунку на 1 кг спожитої сухої речовини корму, оскільки цей спосіб дозволяє створити певну концентрацію сполук, що вивчалася у вмісті рубця.

При додаванні до фоновного раціону 30 г хлористого натрію його концентрація в 1 кг сухої речовини раціону склала 5,3 г; при включенні 0,56 мг Кобальту - 0,23 мг; після додавання 224 мг Цинку - 66,5 мг і після додавання 56 мг Купруму їі концентрація склала 14,8 мг в 1 кг сухої речовини кормів раціону. Мінеральні речовини додавали до фоновного раціону у вигляді розчинів.

Розрахункова кількість доступної для обміну енергії складала 55,8МДж, кількість сирого протеїну в раціоні дорівнювала -574 г.

Таблиця 1

Склад раціонів і споживання поживних і мінеральних речовин бичками

\begin{tabular}{|c|c|c|c|c|c|c|c|c|c|c|c|c|}
\hline Раціони & $\begin{array}{l}\text { № } \\
\Pi / \Pi\end{array}$ & $\mathrm{CP}, \Gamma$ & $\mathrm{OP}, \Gamma$ & СП, г & 量产 & 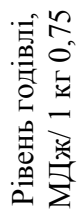 & $\mathrm{Ca}, \Gamma$ & $\mathrm{P}, \Gamma$ & $\mathrm{Na}, \Gamma$ & Со, мг & $\mathrm{Cu}, \mathrm{мг}$ & $\mathrm{Zn}, \mathrm{Mr}$ \\
\hline $\begin{array}{c}\text { Фоновий раціон } \\
\text { (Ф.Р.) }\end{array}$ & 1 & $\begin{array}{c}5631,8 \pm \\
44,9\end{array}$ & \begin{tabular}{|c|}
$5378,8 \pm$ \\
42,6
\end{tabular} & $\begin{array}{c}571,3 \pm \\
2,5\end{array}$ & $\begin{array}{c}55,4 \pm \\
0,43\end{array}$ & 0,78 & $\begin{array}{c}28,2 \pm \\
0,23\end{array}$ & $\begin{array}{c}14,7 \pm \\
0,12\end{array}$ & $\begin{array}{c}4,7 \pm \\
0,03\end{array}$ & $\begin{array}{c}0,74 \pm \\
0,007\end{array}$ & $\begin{array}{c}28,1 \pm \\
0,22\end{array}$ & $\begin{array}{c}154,6 \pm \\
1,2\end{array}$ \\
\hline Ф. p. +30 г $\mathrm{NaCl}$ & 2 & $\begin{array}{c}5646,9 \pm \\
59,8 \\
\end{array}$ & \begin{tabular}{|c|}
$5368,5 \pm$ \\
53,0 \\
\end{tabular} & $\begin{array}{c}570,6 \pm \\
3,2\end{array}$ & $\begin{array}{c}55,2 \pm \\
0,56\end{array}$ & 0,75 & $\begin{array}{c}28,1 \pm \\
0,30\end{array}$ & $\begin{array}{c}14,6 \pm \\
0,15\end{array}$ & $\begin{array}{c}16.3 \pm \\
0,17\end{array}$ & $\begin{array}{c}0,74 \pm \\
0,008\end{array}$ & \begin{tabular}{|c|}
$28,0 \pm$ \\
0,30
\end{tabular} & $\begin{array}{c}154,2 \pm \\
1,6\end{array}$ \\
\hline $\begin{array}{c}\text { Ф. p.+ } 30 \text { г хлор. } \\
\text { натр.+0, } 56 \text { мг } \\
\text { Со }\end{array}$ & 3 & $\begin{array}{c}5641,9 \pm \\
45.1\end{array}$ & $\begin{array}{c}5364,6 \pm \\
39,7\end{array}$ & $\begin{array}{c}570,4 \pm \\
2,4\end{array}$ & $\begin{array}{c}55,2 \pm \\
0,41\end{array}$ & 0,73 & $\begin{array}{c}28,1 \pm \\
0,23\end{array}$ & $\begin{array}{c}14,6 \pm \\
0,12\end{array}$ & $\begin{array}{c}16.3 \pm \\
0,13\end{array}$ & $\begin{array}{l}1,3 \pm \\
0,01\end{array}$ & $\begin{array}{c}28,0 \pm \\
0,22\end{array}$ & $\begin{array}{c}154,0 \pm \\
1,2\end{array}$ \\
\hline $\begin{array}{c}\Phi . \mathrm{p} .+30 \Gamma \\
\mathrm{NaCl} ;+0,56 \mathrm{мг} \\
\mathrm{Co}+56 \mathrm{мг} \mathrm{Cu}+ \\
224 \text { мг } \mathrm{Zn}\end{array}$ & 4 & $\begin{array}{c}5646,9 \pm \\
59,9\end{array}$ & $\begin{array}{c}5368,2 \pm \\
53.3\end{array}$ & $\begin{array}{c}570,6 \pm \\
3,2\end{array}$ & $\begin{array}{c}55,3 \pm \\
0,55\end{array}$ & 0,72 & $\begin{array}{c}28,1 \pm \\
0,30\end{array}$ & $\begin{array}{c}14,7 \pm \\
0,15\end{array}$ & $\begin{array}{c}16,3 \pm \\
0,175\end{array}$ & $\begin{array}{c}1,3 \pm \\
0,01\end{array}$ & $\begin{array}{c}83,4 \pm \\
0,9\end{array}$ & $\begin{array}{c}375,8 \pm \\
4,0\end{array}$ \\
\hline
\end{tabular}

У підготовчий період тварини утримувалися на цьому раціоні два тижні, потім впродовж 7 діб їх використовували в дослідах за визначенням перетравності поживних речовин в шлунково-кишковому тракті. Після завершення досліду по перетравності ставився фізіологічний дослід 3 визначенням добового об'єму і складу хімусу, що протікає через анастомоз. У кормі, середньодобових пробах дуоденального хімусу і калі визначали вміст сухих речовин, а також органічної речовини (за різниці між кількістю сухої речовини і золи) сирого протеїну, сирого жиру, сирої клітковини і безазотистих екстрактивних речовин.

\section{Результати та їх обговорення}

У дослідженнях фоновий раціон (№1) слугував контролем. Дані про кількість хімусу, сухої речовини, органічних сполук і сирого протеїну, що надходили із складного шлунку у дванадцятипалу кишку представлені на рисунках $1-4$.

Максимальну кількість хімусу, що надійшов в тонкий кишечник було відмічено на 3 i 4 раціонах $-77,0$ і 86,8 л відповідно, що перевищило дані контролю на $27,1 \%$ і 44,3\%. Концентрація сухої речовини, органічних сполук і сирого протеїну знижувалася зі збільшенням об'єму хімусу що надходив у дванадцятипалу кишку. Проте загальна кількість сухої і органічної речовин, що надходили в тонкий кишечник при цьому збільшувалася паралельно зі збільшенням об'єму хімусу. Так, з додаванням хлористого натрію органічних речовин в дванадцятипалу кишку надійшло на $23,3 \%$ більше ніж на фоновому раціоні. Додавання до раціону 3 хлористим натрієм Кобальту призвело до збільшення надходження органічних речовин на 37,8\% по відношенню до контролю.

Зі збільшенням об'єму хімусу перетравність органічних речовин в передшлунках знижувалася. (табл. 2).

Найнижча перетравність органічних речовин була відмічена на раціонах №3 і №4 відповідно - 51,1\% i $51,3 \%$. На фоновому раціоні перетравність органічних речовин склала - 64,7\%. Між об'ємом хімусу і перетравністю органічних речовин в рубці встановлена зворотна кореляція: $\mathrm{r}=-0,84$. $\mathrm{P}<0,05$.

Збільшення надходження у тонку кишку органічних речовин пов'язане зі зниженням їх перетравності в складному шлунку зі зміщенням місця перетравлення 3 передшлунків в тонкий відділ кишківника. Надходження сирого протеїну до дванадцятипалої кишки на фоновому раціоні складало 84,5\% по відношенню до прийнятого. На раціоні №2 сирого протеїну надійшло в тонкий кишечник на 160,7 г або $33,3 \%$, а на раціоні №3 на 226,5 г або 55,2\% більше по відношенню до контролю. Встановлена кореляційна залежність між об'ємом хімусу і надходженням сирого протеїну до дванадцятипалої кишки $\mathrm{r}=+0,65$. $\mathrm{P}<0,05$. Слід також відмітити, що якщо на фоновому раціоні сирого протеїну надійшло в дванадцятипалу кишку на 15,5\% менше по відношенню до прийнятого, то на раціонах 3 додаванням мінеральних речовин перевищувало кількість сирого протеїну раціону №1, що пов'язане 3 використанням мікрофлорою не лише азоту зруйнованого сирого протеїну корму, але і ендогенних азотистих сполук, що надходили в порожнину рубця у 
формі сечовини і епітеліальних клітин, які злущуються, сироваткових білків, особливо альбуміну, який поглинається травною системою 3 артеріальної крові (Antipin et al., 2012).

У передшлунках жуйних тварин руйнується значна частина $(60-80 \%)$ сирого протеїну корму. Кількість сирого протеїну і інших органічних речовин, що руйнуються мікрофлорою в рубці залежить від швидкості відтоку рубцевої рідини. Також, інтенсивність біосинтезу мікробіального білку визначається доступністю енергії, що утворюється при зброджуванні органічних речовин в рубці і ряду інших чинників.

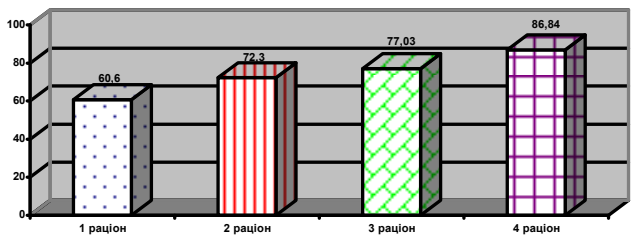

Рис 1. Об'єм хімусу, л/на гол. за добу

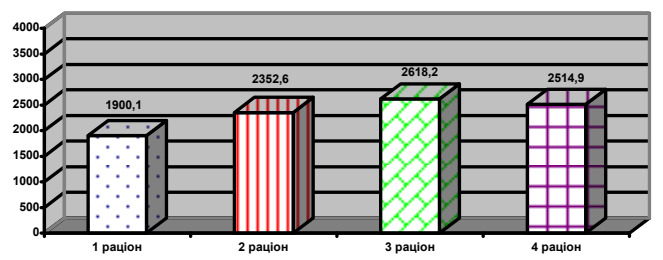

Рис 3. Надходження органічних речовин в кишківник г/добу
Кількість мікробіального сирого протеїну, що утворюється на одиницю енергії або одиницю збродженої органічної речовини, в числі інших чинників, також визначається часом затримки біоти в рубці або швидкістю відтоку рідини з рубця (Antipin et al., 2014).

Таким чином, збільшення відтоку хімусу під впливом мінеральних добавок, що використовувались в дослідах, призвело до підвищення надходження сирого протеїну в кишечник за рахунок збільшення мікробіального синтезу з використанням ендогенних джерел азоту.

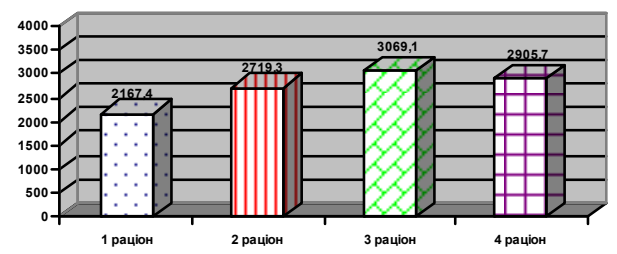

Рис 2. Надходження сухої речовини у кишечник г/за добу

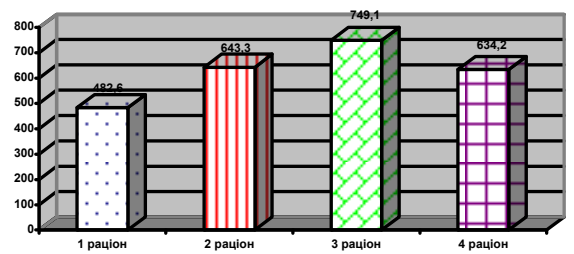

Рис 4. Надходження сирого протеїну в кишечник, г/добу

Табличя 2

Перетравність органічних речовин в складному шлунку (корм - ДПК)

\begin{tabular}{|c|c|c|c|c|}
\hline $\begin{array}{c}\text { Раціони } \\
\text { Показники }\end{array}$ & 1 & 2 & 3 & 4 \\
\hline $\begin{array}{c}\text { Об'єм хімусу літрів, на гол./за } \\
\text { добу }\end{array}$ & $60,60 \pm 3,4$ & $72,30 \pm 2,6$ & $77,03 \pm 3,5$ & $86,84 \pm 6,4$ \\
\hline $\begin{array}{c}\text { Перетравилося ОВ в складному } \\
\text { шлунку (г) }\end{array}$ & $3478,8 \pm 116,6$ & $3015,9 \pm 100,3$ & $2746,6 \pm 155,5$ & $2760,6 \pm 196,4$ \\
\hline $\begin{array}{c}\text { Перетравність ОВ в складному } \\
\text { шлунку (\%) }\end{array}$ & $64,7 \pm 2,0$ & $56,2 \pm 1,8$ & $51,1 \pm 2,7$ & $51,3 \pm 3,4$ \\
\hline
\end{tabular}

Табличяя 3

Надходження сирого протеїну в дванадцятипалу кишку і розрахункове всмоктування білку 3 кишечника

\begin{tabular}{|c|c|c|c|c|}
\hline $\begin{array}{c}\text { Раціони } \\
\text { Показники }\end{array}$ & 1 & 2 & 3 & 4 \\
\hline Надійшло СП в ДПК (г) & $482,6 \pm 29,1$ & $643,3 \pm 30,8$ & $749,1 \pm 44,2$ & $634,2 \pm 43,0$ \\
\hline Надійшло білку в ДПК (г) & 386,1 & 514,6 & 599,3 & 507,4 \\
\hline $\begin{array}{c}\text { Всмокталося білку в тонкому кишечнику } \\
\text { (г) }\end{array}$ & 289,6 & 386,0 & 449,5 & 380,5 \\
\hline
\end{tabular}

За кількістю сирого протеїну, що надійшов до дванадцятипалої кишки, можна розрахувати кількість білку і доступність його для внутрішнього середовища організму, тобто білку, що всмоктується з тонкого кишечника в кров (табл. 3). Прийнято вважати, що в сирому протеїні, що надходить із складного шлунку, міститься 80\% білку, з якого 75\% перетравлюється і всмоктується в кров.
Отримані дані свідчать про те, що на раціонах 3 додаванням мінеральних речовин відбувається збільшення як надходження, так і всмоктування білку 3 кишечника, особливо при підвищенні вмісту кобальту до 0,23 мг в 1 кг сухої речовини раціону. 


\section{Висновки}

1. Додавання до фонового раціону хлориду натрію, Кобальту, Купруму і Цинку викликає значне збільшення відтоку хімусу із складного шлунку в тонкий кишечник і призводить до скорочення часу затримки часток корму в передшлунках бичків.

2. Включення до раціону мінеральних речовин призводить до зниження перетравності органічних речовин в рубці зі зміщенням місця їх перетравлення 3 передшлунків в тонкий кишечник.

3. Збільшення надходження сирого протеїну в тонкий кишечник пов'язане зі зниженням руйнування протеїну корму в рубці і збільшенням біосинтезу мікробіального білку з використанням ендогенних джерел азоту.

\section{Бібліографічні посилання}

Cjupko, V.V. (1987). Metodicheskie rekomendacii po jenergeticheskomu i belkovomu pitaniju krupnogo rogatogo skota. Har'kov (in Ukrainian).
Cjupko, V.V., Jugaj, K.D., Antipin, S.L. i dr. (1995). Normirovannoe kormlenie krupnogo rogatogo skota molochnogo i kombinirovannogo napravlenija produktivnosti. Metodicheskie rekomendacii IZh UAAN. Har'kov (in Ukrainian).

Antipin, S.L., Zhukova, I.A., Jugaj, K.D., Bobrickaja, O.N., Vodop'janova, L.A. (2012). Vlijanie mineral'nyh dobavok $\mathrm{k}$ racionu na obmen mineral'nyh veshhestv v kishechnike bychkov, Problemi zooinzhenerii ta vetmedicini. Zbirnik nauk prac'. Harkiv. 25(2), 28-31 (in Ukrainian).

Antipin, S.L., Zhukova, I.A., Jugaj, K.D., Longus, N.I., Kochevenko, O.S. (2014). Vzaєmozv'jazok mizh procesami biosintezu u peredshlunkah zhujnih tvarin i vmistom mineral'nih rechovin u racionah, Visnik Sums'kogo nacional'nogo agrarnogo universitetu. Naukovij zhurnal. Sumi. Serija «Veterinarna medicina». 6 (35), 18-21 (in Ukrainian).

Стаття надійшла до редакиії 29.09.2016 